\title{
Motor Recovery after Transplantation of Bone Marrow Mesenchymal Stem Cells in Rat Models of Spinal Cord Injury
}

\author{
Durai Murugan Muniswami ${ }^{\mathrm{a}}$ Praghalathan Kanthakumar ${ }^{\mathrm{b}}$ \\ Indirani Kanakasabapathy ${ }^{c}$ George Tharion ${ }^{a}$ \\ aDepartment of Physical Medicine and Rehabilitation, Christian Medical College, Vellore, India; ${ }^{b}$ Department \\ of Physiology, Christian Medical College, Vellore, India; ' Department of Anatomy, Christian Medical College, \\ Vellore, India
}

\section{Keywords}

Spinal cord injury - Mesenchymal stem cells .

Transplantation - Basso, Beattie, Bresnahan score .

Electromyography

\begin{abstract}
Background: Neuronal tissue has a limited potential to selfrenew or get repaired after damage. Cell therapies using stem cells are promising approaches for the treatment of central nervous system (CNS) injuries. However, the clinical use of embryonic stem cells is limited by ethical concerns and other scientific consequences. Bone marrow mesenchymal stromal cells (BM-MSC) could represent an alternative source of stem cells for replacement therapy. Indeed, many studies have demonstrated that MSCs can give rise to neuronal cells as well as many tissue-specific cell phenotypes. Purpose: Motor recovery by transplantation of bone marrow MSCs in rat models of spinal cord injury (SCl). Methods: Bone marrow
\end{abstract}

was collected from the femur of albino Wistar rats. MSCs were separated using the Ficoll-Paque density gradient method and cultured in Dulbecco's Modified Eagle Medium supplemented with $20 \%$ fetal bovine serum. Cultured MSC was characterized by immunohistochemistry and flow cytometry and neuronal-induced cells were further characterized for neural markers. Cultured MSCs were transplanted into the experimentally injured spinal cord of Wistar rats. Control (injured, but without cell transplantation) and transplanted rats were followed up to 8 weeks, analyzed using the Basso, Beattie, Bresnahan (BBB) scale and electromyography (EMG) for behavioral and physiological status of the injured spinal cord. Finally, the tissue was evaluated histologically. Results: Rat MSCs expressed positivity for a panel of MSC markers CD29, CD54, CD90, CD73, and CD105, and negativity for hematopoietic markers CD34, CD14, and CD45. In vitro neuronal transdifferentiated MSCs express positivity for $\beta$ III tubulin, MAP2, NF, NeuN, Nav1.1, oligodendrocyte (O4), and negativity for glial fibrillary acid protein. All the treated groups

\section{KARGER}

(c) 2018 S. Karger AG, Basel

E-Mail karger@karger.com

www.karger.com/aon
Dr. Durai Murugan Muniswami, PhD

Department of Physical Medicine and Rehabilitation

Christian Medical College

Vellore-632004, Tamil Nadu (India)

E-Mail durai.morgan@gmail.com, duraimorgan@cmcvellore.ac.in 
show promising hind-limb motor recovery BBB score, except the control group. There was increased EMG amplitude in treated groups as compared to the control group. Green fluorescent protein (GFP)-labeled MSC survived and differentiated into neurons in the injured spinal cord, which is responsible for functional recovery. Conclusion: Our results demonstrate that BM-MSC has the potential to repair the injured cord in rat models of SCl. Thus, BM-MSC appears to be a promising candidate for cell-based therapy in CNS injury.

(C) 2018 S. Karger AG, Basel

\section{Introduction}

Traumatic spinal cord injury (SCI) can result in severe damage, leading to permanent loss of mobility, incontinence, and other functional loss. Surgical re-stabilization of the vertebral column and rehabilitation are the current therapies available, since there are no effective treatments to cure neurological outcomes following SCI. The pathophysiology of SCI involves primary mechanical injury that directly disrupts axons, blood vessels, and the cell membrane. This primary mechanical injury is followed by the secondary injury phase involving vascular dysfunction, edema, ischemia, excitotoxicity, electrolyte shifts, free radical production, inflammation, and delayed apoptotic cell death $[1,2]$. Following injury, the mammalian central nervous system (CNS) fails to adequately regenerate due to intrinsic inhibitory factors expressed on central myelin and the extracellular matrix of the posttraumatic gliotic scar [3]. Regenerative approaches to block inhibitory signals, including Nogo and the Rho-associated kinase pathways, have shown promising benefits and are in their early stages of clinical evaluation [4]. Cellbased strategies using embryonic stem cell, neural stem cells, bone marrow-derived mesenchymal stromal/stem cells (BM-MSCs) to remyelinate spared axons are attractive emerging approaches [5].

Bone marrow is a source of hematopoietic cells and non-hematopoietic marrow MSCs. MSCs are multipotent [6] and self-renewing; they can differentiate into osteoblasts $[7,8]$, chondrocytes [9], adipocytes [10], and also neurons and glia [11]. BM-MSCs are easily obtainable, autologous, expand quickly, and differentiate into neural cell types in vitro [12-16] and in vivo [17-19]. It has been reported that MSCs transplanted into the spinal cord lesion site enhance axonal regeneration and promote functional recovery in animal models [20-26]. In addition, it is believed that MSCs lack B7 co-stimulatory molecules CD86 and CD80 and are non-immunogenic upon allogeneic transplantation [27]. The overall effect of MSC is to rescue neuronal cells from death by neuroprotection, immunomodulation, and possibly by remyelination and neuroregeneration $[28,29]$. These factors suggest that MSC has a role in treating irreversible damages to the CNS like SCI.

We harvested bone marrow from the femur bone of adult male albino Wistar rats; we also separated MSCs by the Ficoll-Paque density gradient method and these cells were cultured. The cultured cells were transplanted into the experimentally induced SCI of rat models. The functional outcome was measured by the Basso, Beattie, Bresnahan (BBB) scale, electromyography (EMG), and histological methods.

\section{Methods}

Adult albino Wistar rats were used for the study. The animals were obtained from the animal house of the institution. The study was approved by the institutional review board and the institution's animal ethical committee.

\section{Isolation of MSC}

Bone marrow was collected from the femur and tibia of albino Wistar rats. The MSCs were separated from hematopoietic cells by using the RosetteSep Antibody Cocktail method (Stemcell Technologies Inc.). Bone marrow cell suspension was incubated with the RosetteSep cocktail for $20 \mathrm{~min}$ at room temperature. This cocktail cross-links the undesired cells in bone marrow, thereby forming immune rosettes. This increases the density of the unwanted (rosetted) cells, such that they pellet along with the free red blood corpuscles when centrifuged at $1,200 \mathrm{~g}$ for $20 \mathrm{~min}$ over a buoyant density medium Ficoll-Paque (GE Healthcare). Desired cells that did not bind to the antibody were easily collected as a highly enriched population at the interface (buffy coat) between the plasma and the buoyant density medium. Mononuclear cells from buffy coat were washed in phosphate buffered saline (PBS) and cultured.

\section{Culture of MSC}

The cell culture medium consisted of Dulbecco's Modified Eagle Medium (DMEM) (Gibco), supplemented with 20\% fetal bovine serum (Gibco), $2 \mathrm{mM}$ L-glutamine (Gibco-Invitrogen), $100 \mathrm{U} / \mathrm{mL}$ penicillin, $100 \mu \mathrm{g} / \mathrm{mL}$ streptomycin, and $25 \mathrm{ng} / \mathrm{mL}$ of amphotericin B. When the cells attain $80-90 \%$ confluency, they are passaged with trypsin up to the second passage. Second passage cells were used for immunohistostaining, flow cytometry analysis, and patch-clamp characterization.

\section{Characterization of MSCs by Immunohistochemistry}

Second passage cells were cultured on $12-\mathrm{mm}$ round coverslips at a cell density of 8,000 cells $/ \mathrm{cm}^{2}$. Cells were fixed in $4 \%$ paraformaldehyde for $15 \mathrm{~min}$ at room temperature. Then the cells were washed with PBS (Invitrogen, Gibco) 3 times. Blocking and permeabilization was done using $2 \%$ goat serum $/ 2 \%$ bovine serum albumin with $0.1 \%$ Triton X-100\PBS. Cells were incubated with 
primary antibody at $4{ }^{\circ} \mathrm{C}$ overnight. Cells were washed with PBS and incubated with secondary antibody for $2 \mathrm{~h}$ at room temperature. They were then washed and mounted with 4',6-diamidino2-phenylindole (DAPI; Vectashield mounting medium with DAPI). Coverslips were immediately transferred to glass slides and examined in fluorescent microscope. The following primary and secondary fluorescent antibodies were used for this characterization study: mouse anti-rat CD54-FITC conjugated antibody (1:50 dilution, BD Pharmingen), monoclonal mouse anti-rat CD90FITC conjugated antibody (1:100 dilution, Millipore), mouse monoclonal IgG1 anti-CD34-FITC conjugated antibody (1:100 dilution, Santa Cruz Biotechnology), mouse monoclonal anti-rat CD45-PE conjugated antibody (1:100 dilution, BD Pharmingen), rabbit polyclonal IgG anti-CD14 antibody (1:50 dilution, Santa Cruz biotechnology), monoclonal mouse anti- $\beta 1$ integrin antibody (1:50 dilution, Millipore), monoclonal mouse anti-rat CD73 antibody (1:50 dilution, BD Pharmingen), goat polyclonal IgG anti-CD105 antibody (1:25 dilution, Santa Cruz Biotechnology), mouse monoclonal anti-MAP2 IgG1 antibody (1:100 dilution, Millipore), mouse monoclonal anti-NeuN IgG1 antibody (1:50 dilution, Millipore), and mouse monoclonal anti-Neurofilament IgG1 antibody (1:100 dilution, Millipore), with appropriate secondary antibodies like goat anti-rabbit IgG-RPE antibody (1:50 dilution, Jackson ImmunoResearch), goat anti-mouse IgG2b-RPE antibody (1:50 dilution, Southern Biotech), goat anti-mouse IgG1PE conjugated antibody (1:50 dilution, Southern Biotech), donkey anti-goat IgG-perCP conjugated antibody (1:100 dilution, Jackson ImmunoResearch), and goat anti-mouse IgG1-FITC antibody (1: 50 dilution, Southern Biotech).

\section{Characterization of MSC by Flow Cytometry}

Second passage cells were trypsinized and washed with PBS. A total of 2-5 lakhs of cells were used for each antibody in a separate test tube and incubated with $5-10 \mu \mathrm{L}$ of primary antibody for 20 min on ice. Excess unbound antibodies were washed with PBS and removed. Further, this was incubated with $5-10 \mu \mathrm{L}$ of fluorescent tagged appropriate secondary antibody for $20 \mathrm{~min}$. Finally, unbound secondary antibodies were washed with PBS. The cell suspension was aspirated and analyzed by flow cytometry for MSC markers (CD54, CD90, CD73, CD29, and CD105) and hematopoietic markers (CD45, CD34, CD14). The unstained cells were used as control.

\section{Neuronal Induction of MSC}

The neuronal induction protocol was followed from an earlier published study [11]. Second passage MSCs were induced to neuronal cells by using neuronal induction medium consisting of DMEM/F12 (Invitrogen, Gibco), 2\% FBS (Invitrogen, Gibco), B27 supplement (Invitrogen, Gibco), 20 mM retinoic acid (RA; Sigma), and $12.5 \mathrm{ng} / \mathrm{mL}$ basic fibroblast growth factors (bFGFs; Invitrogen, Gibco). Cells were maintained in neuronal induction media for 12 days at $37^{\circ} \mathrm{C}$ in $5 \% \mathrm{CO}_{2}$ incubator. After 12 days, these cells were stained for neuronal markers and patch-clamp study.

\section{Characterization of Neuronal-Induced Cells}

Bone marrow MSC (BM-MSC) was incubated for 12 days in the neuronal induction medium, and these cells were stained for neuronal and glial markers using fluorescent staining. We used the following primary and secondary antibodies by the immunohistochemistry method as described above: mouse monoclonal anti- $\beta$
III tubulin antibody (1:50 dilution, Millipore), mouse monoclonal IgG1 anti-glial fibrillary acid protein (GFAP) Alexa Fluor 488 conjugated antibody (1:50 dilution, eBioscience), mouse monoclonal IgM anti-oligodendrocyte antibody (1:50 dilution, Sigma), rabbit polyclonal anti-Nav1.1 antibody (1:100 dilution, Alomone labs), and mouse IgG2A neuron-specific $\beta$-III tubulin PerCP conjugated antibody (1:100 dilution, R\&D systems), with appropriate secondary antibodies like goat anti-mouse rhodamine antibody (1:50 dilution, Millipore), donkey anti-mouse IgM-CY3 conjugate antibody (1:50 dilution, Jackson ImmunoResearch), and goat antirabbit IgG-PE antibody (1:50 dilution).

\section{Electrophysiology}

The pipette solution contained the following: $140 \mathrm{mM}$ potassium chloride $(\mathrm{KCl}), 1 \mathrm{mM}$ magnesium chloride $\left(\mathrm{MgCl}_{2}\right), 1 \mathrm{mM}$ ethylene glycol-bis( $\beta$-aminoethyl ether)-N,N,N',N'-tetraacetic acid (EGTA), $10 \mathrm{mM}$ 4-(2-hydroxyethyl)-1-piperazineethanesulfonic acid (HEPES), and $10 \mathrm{~mm}$ glucose; $\mathrm{pH} 7.2$ with potassium hydroxide $(\mathrm{KOH})$. The bath solution for recording contained the following: $135 \mathrm{mM}$ sodium chloride $(\mathrm{NaCl}), 1 \mathrm{mM}$ sodium dihydrogen phosphate $\left(\mathrm{NaH}_{2} \mathrm{PO}_{4}\right), 4 \mathrm{mM} \mathrm{KCl}, 1.2 \mathrm{mM}$ calcium chloride $\left(\mathrm{CaCl}_{2}\right), 0.5 \mathrm{MgCl}_{2}, 10 \mathrm{~mm}$ HEPES, and $10 \mathrm{~mm}$ glucose; $\mathrm{pH} 7.4$ with sodium hydroxide $(\mathrm{NaOH})$.

The second passage MSCs/neuronal-induced cells were placed on a $35 \mathrm{~mm}$ petri-dish with $2 \mathrm{~mL}$ bath solution. Patch pipettes were fabricated using borosilicate glass capillaries by using a gravityassisted 2-stage pipette puller. The pipette tips were heat polished and coated with sylgard. The pipette was filled with a pipette solution and the pipette resistance ranged between 2 and $4 \mathrm{M} \Omega$. The bath and pipette solutions were designed to elicit sodium, potassium, and chloride currents.

Once a gigaohm seal was obtained between the patch pipette and the cell membrane, whole cell configuration was established by applying sharp suction. Cell capacitance was cancelled. The series resistance before compensation was below $15 \mathrm{M} \Omega$, and was compensated $60-70 \%$. The holding voltage was $-50 \mathrm{mV}$, and a prepulse of $-40 \mathrm{mV}$ was given to elicit the voltage-gated sodium current (if it was present), before the test pulse. The test pulse ranged from -110 to $180 \mathrm{mV}$ at $10 \mathrm{mV}$ increment. The data during voltage clamp was acquired using Axopatch 200B patch-clamp amplifier and digitized with Axon instruments Digidata 1322A analog-digital converter. The data was filtered using online $10 \mathrm{kHz}$ low pass Bessel filter. P-clamp software was used for acquisition and analysis of the data.

\section{Green Fluorescent Protein Labeling of Cells}

A total of $0.5 \times 10^{5} / \mathrm{mL}$ cells were grown in complete medium overnight. At the time of transduction, they were $50-75 \%$ confluent, and were added to $50 \mu \mathrm{L}$ of $1 \times 10^{7} \mathrm{IFU} / \mathrm{mL}$ of pre-made lentiviral particles for fluorescent proteins (catalog number: LVP001, GenTarget Inc., USA). After $72 \mathrm{~h}$ of transduction, the transduction rate was checked using a fluorescent microscope. These green fluorescent protein (GFP)-labeled cells were used for transplantation.

\section{Cell Viability}

Freshly cultured second passage cells were harvested and kept on ice for $2 \mathrm{~h}$. These cells were stained for propidium iodide - a red fluorescent DNA counterstain. Both unstained and stained cells were quantified through flow cytometry. Dead cells stains with propidium iodide and live cells do not take up the stain. 


\section{Animal Experiments}

\section{Experiment Design}

Rats were divided into 5 groups $(n=6$ rats in each group). BM-MSCs were transplanted in dosages of 2, 5, 10 , and $>10$ lakhs, respectively, in each of the first 4 groups, whereas only DMEM without cells was used in the control group.

\section{Laminectomy and SCI}

Female albino Wistar rats, 100-250 g in body weight, were anesthetized with ketamine and xylazine (90:10 $\mathrm{mg} / \mathrm{kg}$ ) administered intraperitoneally. Ophthalmic ointment was applied to the eyes to prevent drying during the operation. The fur was shaved from the mid dorsal region and cleaned with povidone-iodine solution $(7.5 \% \mathrm{w} / \mathrm{v})$ finally with surgical spirit. Tegaderm applied over it to prevent fur contamination during surgery. An incision of $2 \mathrm{~cm}$ was made over the lower thoracic area; muscle and connective tissues were dissected to expose the T7-T11 vertebrae. A T10 laminectomy was completed using a microsurgery bone rongeur taking care not to damage the spinal cord. The drop-weight injury was performed, $10 \mathrm{~g}$ weight rod falls from $25 \mathrm{~cm}$ height on the exposed spinal cord. Absorbable sutures (Vicryl, Johnson-Johnson Ltd.) were used to ligate the incised muscle and skin. The following was administered subcutaneously as part of the postoperative care: meloxicam $1 \mathrm{mg} / \mathrm{kg}$ as analgesic, enrofloxacin $2.5 \mathrm{mg} / \mathrm{kg}$ as antibiotic, and Ringer's lactate $5 \mathrm{~mL} / 100 \mathrm{~g}$. Animals had free access to food and water throughout the study. Bladder and bowel expression were considered as postoperative care.

\section{Postoperative Care}

Following the surgery, rats were placed in cages and monitored until they recovered from anesthesia. Rats were monitored twice a day throughout the post-injury survival period for general health and mobility. The bladder was manually expressed twice daily. Ringer's lactate $5 \mathrm{~mL} / 100 \mathrm{~g}$ was administered subcutaneously twice daily for the first 7 postoperative days. Meloxicam $1 \mathrm{mg} / \mathrm{kg}$ as analgesic and enrofloxacin $2.5 \mathrm{mg} / \mathrm{kg}$ as antibiotic were administered for the first 7 postoperative days. Animals were monitored for urinary tract infections (UTI) for the entire period of the experiment. If indicative of a UTI, they were treated with the antibiotics (enrofloxacin $2.5 \mathrm{mg} / \mathrm{kg}$ ). Inspection for skin ulcers was carried out daily. Bedding (paddy husk) was changed every alternate day.

Motor Recovery after Transplantation of BM-MSCs Rat Models of Spinal Cord Injury

\section{Cell Transplantation}

Allogeneic cell transplantation was done on the 9th day following the drop-weight injury. Behavioral assessment (BBB) was conducted prior to the cell transplantation as described later. Rats were re-anesthetized (intraperitoneal ketamine/xylazine: $90: 10 \mathrm{mg} / \mathrm{kg}$ ), and the original incision was re-opened and the dorsal laminectomy was extended to the T8-T11 vertebrae. Under a surgical microscope, the wound was explored and the injured spinal cord segment, along with a few millimeters above and below normal spinal cord, was exposed. On the day of transplantation, the MSCs were harvested by trypsinization after which the enzymatic activity was stopped by adding DMEM with fetal bovine serum. Cells were counted and pelleted and transferred into the $25 \mu \mathrm{L}$ Hamilton syringe (approximately 100,000 cells $/ \mu \mathrm{L}$ ). A Hamilton syringe was mounted on an injection device with $3 \mathrm{D}$ stabilizer. All injections were made with the aid of a sterile Hamilton syringe. A total of $2 \times 10^{5}$ (2 lakhs), $5 \times 10^{5}$ (5 lakhs), $10 \times 10^{5}$ (10 lakhs), and more than $10 \times 10^{5}$ (>10 lakhs) cells were injected at multiple sites in and around the injured spinal cord. Following the cell transplantation, the surgical wound was closed and routine postoperative care was given.

\section{Behavioral Assessment-BBB Score}

The BBB scale [30] is an operationally defined 21-point scale, designed to assess hind-limb locomotor recovery after impact injury to the spinal cord in rats. This locomotor scale categorizes the combination of rat hind limb joint movements, trunk position and stability, stepping, coordination, paw placement, toe clearance, and tail position, representing sequential recovery stages that rats attain after SCI. The motor assessment is done up to 8-10 weeks after injury/transplant. Openfield observations were made on rats. All rats received bladder expression before open field testing to eliminate behaviors because of a full bladder. Rats were allowed to walk in the open field $(45 \times 60 \mathrm{~cm}$ rectangular tray) and video recorded for assessment. All rats were assessed for BBB before transplant, that is, on the 9th day after SCI and every week from the time of post-transplant up to 8-10 weeks. The BBB score was measured with the aid of the BBB scale.

\section{Motor Evoked Potential Studies}

Transcranial stimulation of motor cortex was done in the anesthetized rats and the EMG signals were recorded from the lower limb muscles to indicate the functional 
integrity of the spinal cord. Motor cortex was stimulated and the responses were recorded from the gastrosoleus muscles. Recording was done from control as well as cell transplanted rats at 8-10 weeks post spinal injury/transplantation. Recorded EMG signals were analyzed for amplitude. The amplitude of electrical stimulation assessed for mean \pm SD and all the groups was compared for $p$ values.

\section{Histology}

Two weeks after GFP-labeled MSC transplantation, rats were deeply anesthetized with ketamine/xylazine and transcardially perfused with $4 \%$ paraformaldehyde solution. One centimeter length of spinal cord centered on the injury epicenter was removed and post-fixed in 30\% sucrose/PBS at $4{ }^{\circ} \mathrm{C}$ overnight. Thick longitudinal serial cryo sections of $20 \mu \mathrm{m}$ were cut and mounted on poly-LLysine-coated slides. The representative tissue section was incubated with $0.3 \%$ Triton X-100/PBS overnight at $4{ }^{\circ} \mathrm{C}$. The tissue was washed with PBS and incubated with the primary antibody, mouse monoclonal anti-B III tubulin (1:50 dilution, Millipore), at $4^{\circ} \mathrm{C}$ overnight. After PBS wash, the tissue was incubated with the secondary antibody, goat anti-mouse rhodamine (1:50 dilution, Millipore), for $2 \mathrm{~h}$ at room temperature. Finally, the tissue section was washed with PBS and visualized using a confocal microscope.

\section{Statistical Analysis}

Hind-limb motor recovery was analyzed using $\mathrm{BBB}$ scores, amplitude of motor evoked potential were statistically analyzed by using SPSS, and ANOVA post hoc Tukey test was to compare significances with different groups. Wilcoxon test and Mann-Whitney test were also done. Data for each group were represented as mean \pm SD. $p$ value $<0.05$ was considered significant in this study.

\section{Results}

\section{MSC Characterization}

BM-MSC expression of the markers CD54, CD29, CD73, CD90, and CD105 showed positivity of about 40, $82,85,99$, and $13 \%$, respectively; and for hematopoietic markers CD14, CD45, and CD34 showed negativity of about 0,0 , and $2 \%$, respectively, which indicates the purity of MSC (Fig. 1, 2). In addition, MSC expressed negativity for mature neuron markers of MAP2, NeuN, and neurofilament (NF), as well (Fig. 3).

\section{Neuronal-Induced MSC}

Morphological changes expressed were the change in fibroblast-like to spindle shape in vitro after 12 days (Fig. 4). MSCs showed negative for neuronal markers MAP2, NeuN, and NF, but after neuronal induction these cells expressed positivity for the differentiated markers of neuron (MAP2, NF, Neuronal neuclei, $\beta$ III tubulin) and oligodendrocyte $(\mathrm{O} 4)$, and negativity for astrocyte (GFAP). This shows that MSC is capable of transdifferentiation, from mesodermal origin MSC to ectodermal neuronal lineages (Fig. 4).

\section{Electrophysiology}

Voltage-gated sodium channel is essential for the generation and propagation of action potential. This is the hallmark for the excitable cell neuron. Our results show the expression of voltage-gated sodium channel type 1 (Nav1.1) immunohistochemically (Fig. 5) but did not have functional expression of voltage-gated sodium by patch-clamp studies in neuronal-induced cells. Uninduced MSCs did not exhibit voltage-gated sodium channels at the prepulse potential of $-40 \mathrm{mV}$. Small outward currents activating at about $-40 \mathrm{mV}$ were seen (Fig. 6a). Neuronal transdifferentiated cells exhibit outwardly rectifying $\mathrm{K}^{+}$current, with the absence of inward $\mathrm{Na}^{+}$current at $-40 \mathrm{mV}$ and further depolarization (Fig. 6b).

\section{Cell Viability}

Before transplantation, the cell viability was assessed by propidium iodide and only $3 \%$ of dead cells were quantified (Fig. 7).

Basso, Beattie, Bresnahan

Sequential hind-limb motor recovery was elicited in all treated groups except the control group (Fig. 8a). Before transplant, all the groups showed no BBB score $(0.00 \pm$ 0.00 ); but after transplantation, the 4 groups (except the control group) showed BBB of 2 lakh ( $2.5 \pm 1.378), 5$ lakh $(6.0 \pm 2.756), 10$ lakh $(4.3 \pm 3.141)$, more than 10 lakh $(3.8 \pm 2.994)$, respectively, which shows statistical significances $(p<0.05)$ in hind-limb motor recovery after transplantation (Fig. 8b).

All the treated groups exhibit functional recovery with variation in BBB scores at the end of the 8th week as compared to the control group $(0.0 \pm 0.00)$. The 5-lakh and 10 -lakh groups showed statistical significance $(p<0.05)$, but a low dose of 2 lakh and a high dose of more than 10 lakh did not show significance $(p>0.05)$, when compared to the control group. Although the same cells with different dosage have different effects on motor recovery, on statistical analysis, it was found that there is no significant DOI: $10.1159 / 000487069$
Muniswami/Kanthakumar/ Kanakasabapathy/Tharion 


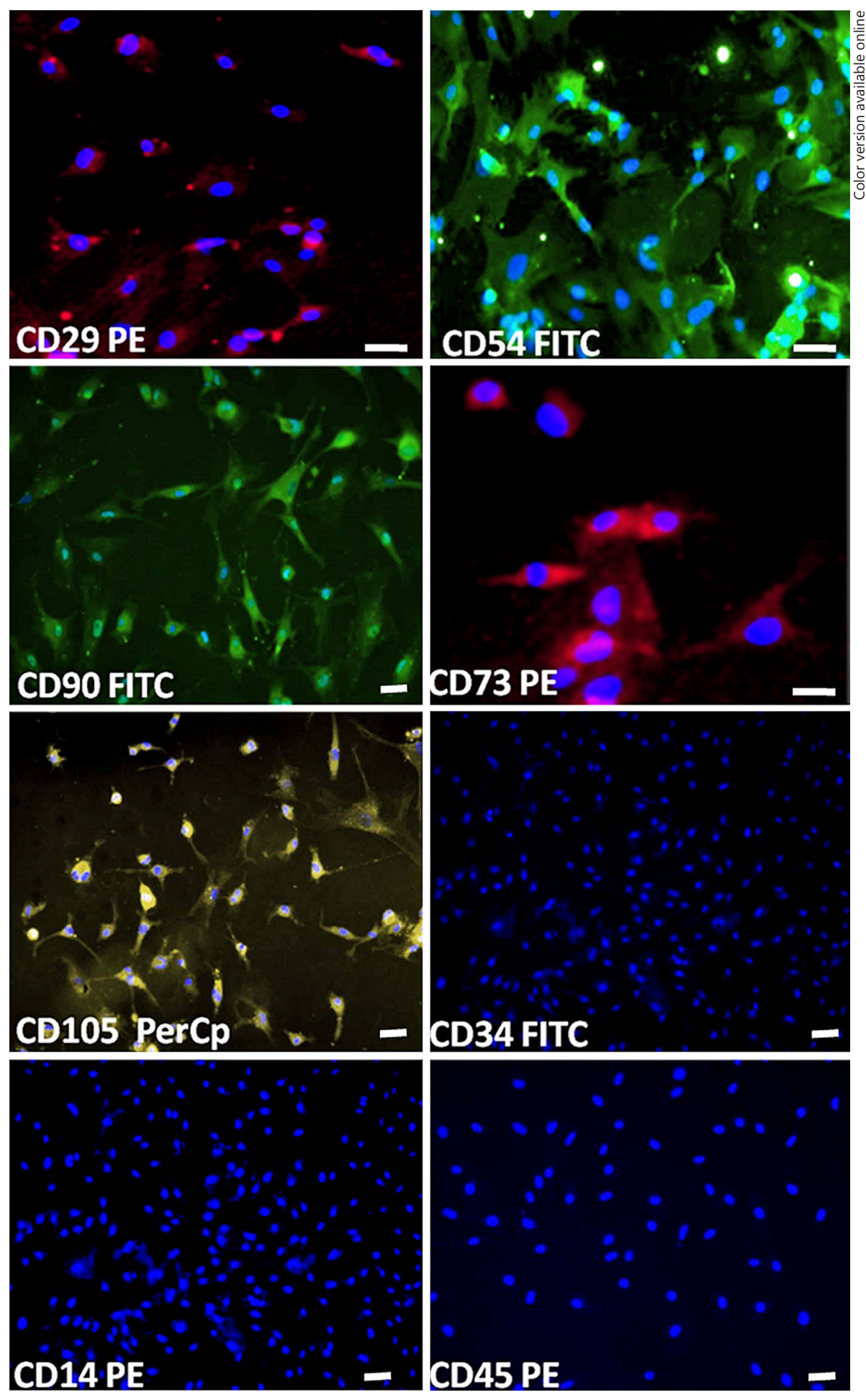

Fig. 1. Immunohistochemical characterization of rat MSC. Rat MSCs express positivity for the panel of markers CD29, CD54, CD90, CD73, and CD105 and negativity for hematopoietic markers CD34, CD14, and CD45. (Scale bar $=20 \mu \mathrm{m}$ for CD29, CD54, and CD73 and $10 \mu \mathrm{m}$ for CD90, CD105, CD34, CD14, and CD45).

difference among the transplanted groups (Fig. 8c). However, in dose-response relationship, 5 lakhs of MSC show a promising maximum mean BBB score of 6 as compared to other dosages.

Motor Recoveryafter Transplantation of BM-MSCs Rat Models of Spinal Cord Injury

\section{Electromyography}

Though transplanted cells are MSCs, they differ in dosage, and these doses have an impact on recovery as analyzed by the motor-evoked potential in amplitude. A rep-

Ann Neurosci 2018;25:64-78 

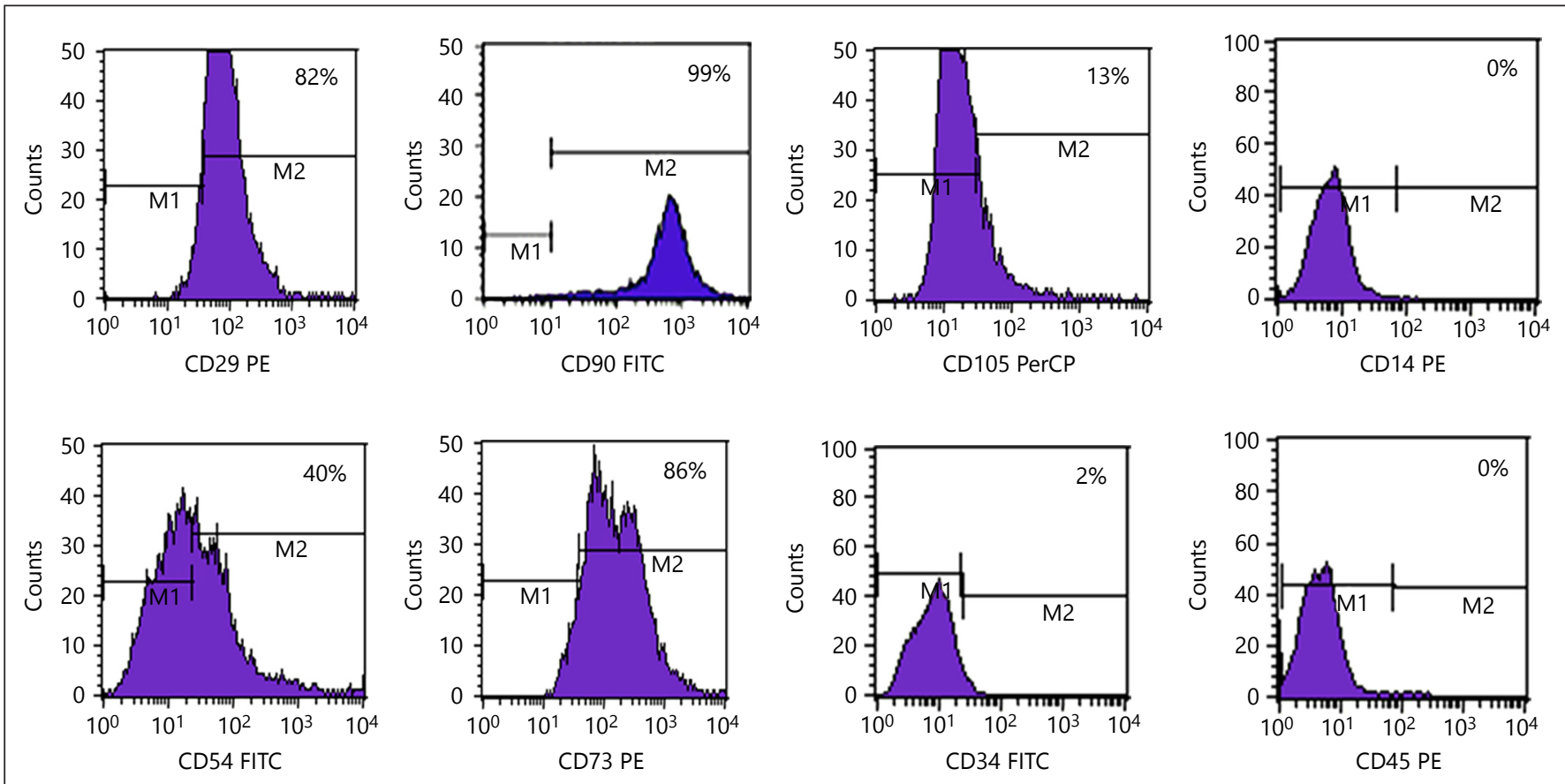

Fig. 2. Surface marker expression of rat MSCs. Flow cytometry analysis of the immunophenotypic surface profiles for CD29, CD54, CD90, CD73, CD105, CD34, CD14, and CD45 of cultured MSCs. Histograms represent the counts of cells incubated with the relevant antibody. The logarithm on the $\mathrm{x}$-axis represents the in- tensity of the fluorescent signal and the number of cells on the $y$ axis. Second passage cultured MSCs were positive for the markers CD29, CD54, CD73, CD90, and CD105 but negative for CD34, CD14, and CD45.
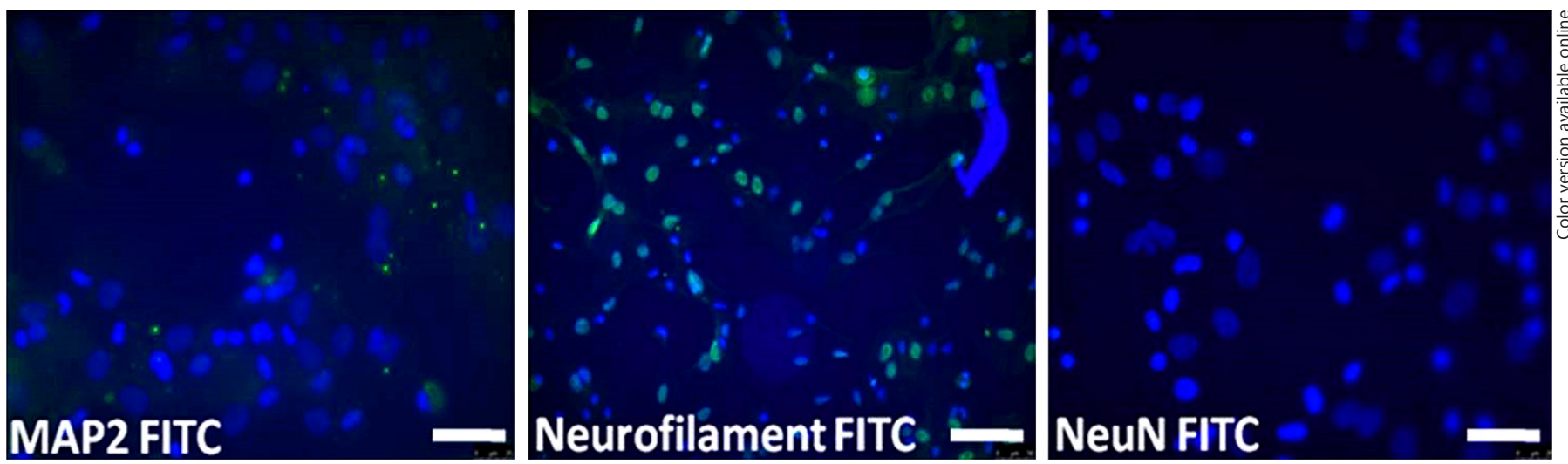

Fig. 3. Characterization of rat MSCs for neuronal markers. Photomicrographs of in vitro rat MSC showed negative for mature neuronal markers (MAP2, neurofilament, NeuN). Scale bar $=20 \mu \mathrm{m}$.

resentative EMG of control rat (Fig. 9a) and treated rat (Fig. 9b) was shown with/without amplitude. All the transplanted groups' EMG amplitude of 2 lakh (0.4 \pm 0.166$), 5$ lakh (1.5 \pm 1.062$), 10$ lakh $(1.2 \pm 1.100)$, and more than 10 lakh $(0.6 \pm 0.334)$ were statistically analyzed with that of the control group $(0.1 \pm 0.086)$, which did not show sig- nificant difference $(p>0.05)$, except the 5-lakh group $(p=$ $0.01)$. In the low dose of 2-lakh group, decreased amplitude was exhibited, which indicates less amount of regeneration after SCI. The 5-lakh group demonstrates maximum amplitude similar to the BBB score, but increase in dosages above 5 lakh shows decline in amplitude (Fig. 9c). 

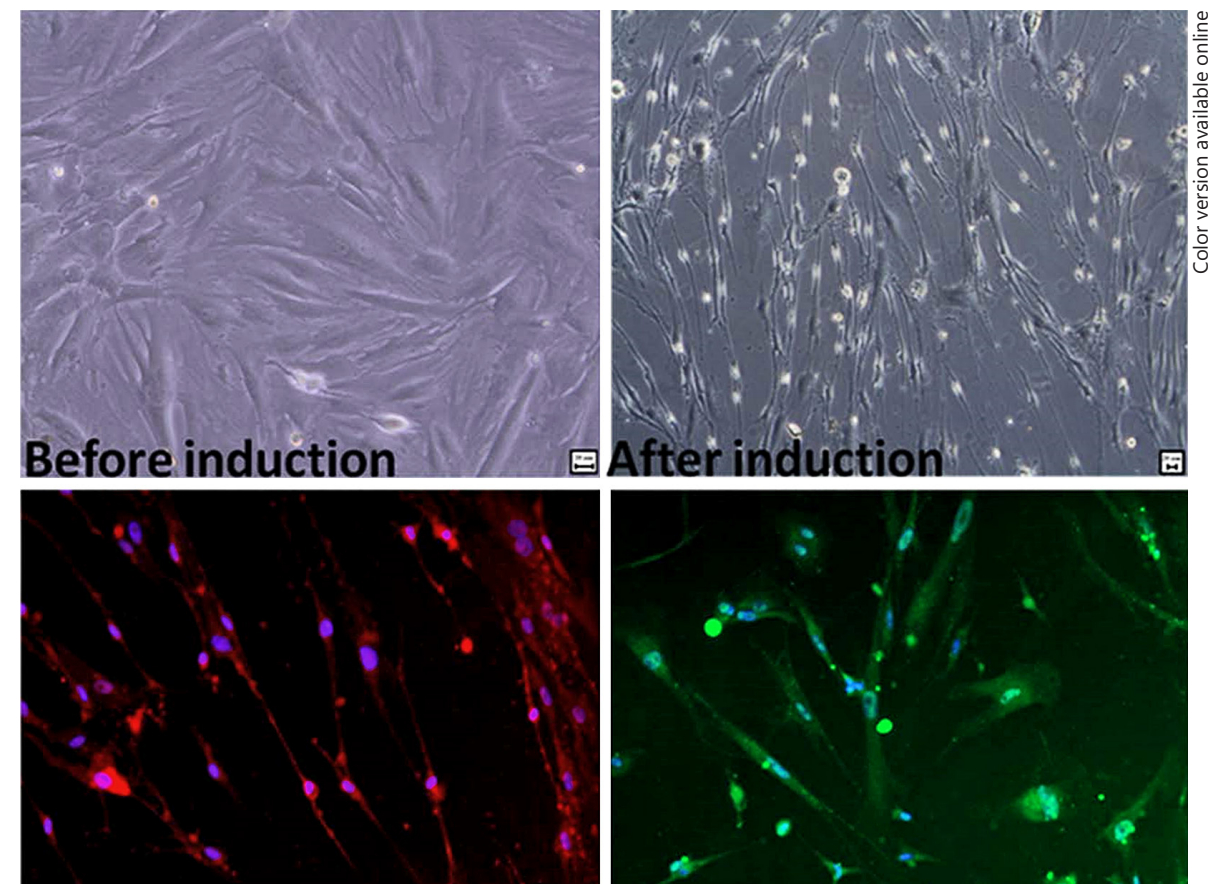

\section{B III tubulin Rhodamine}
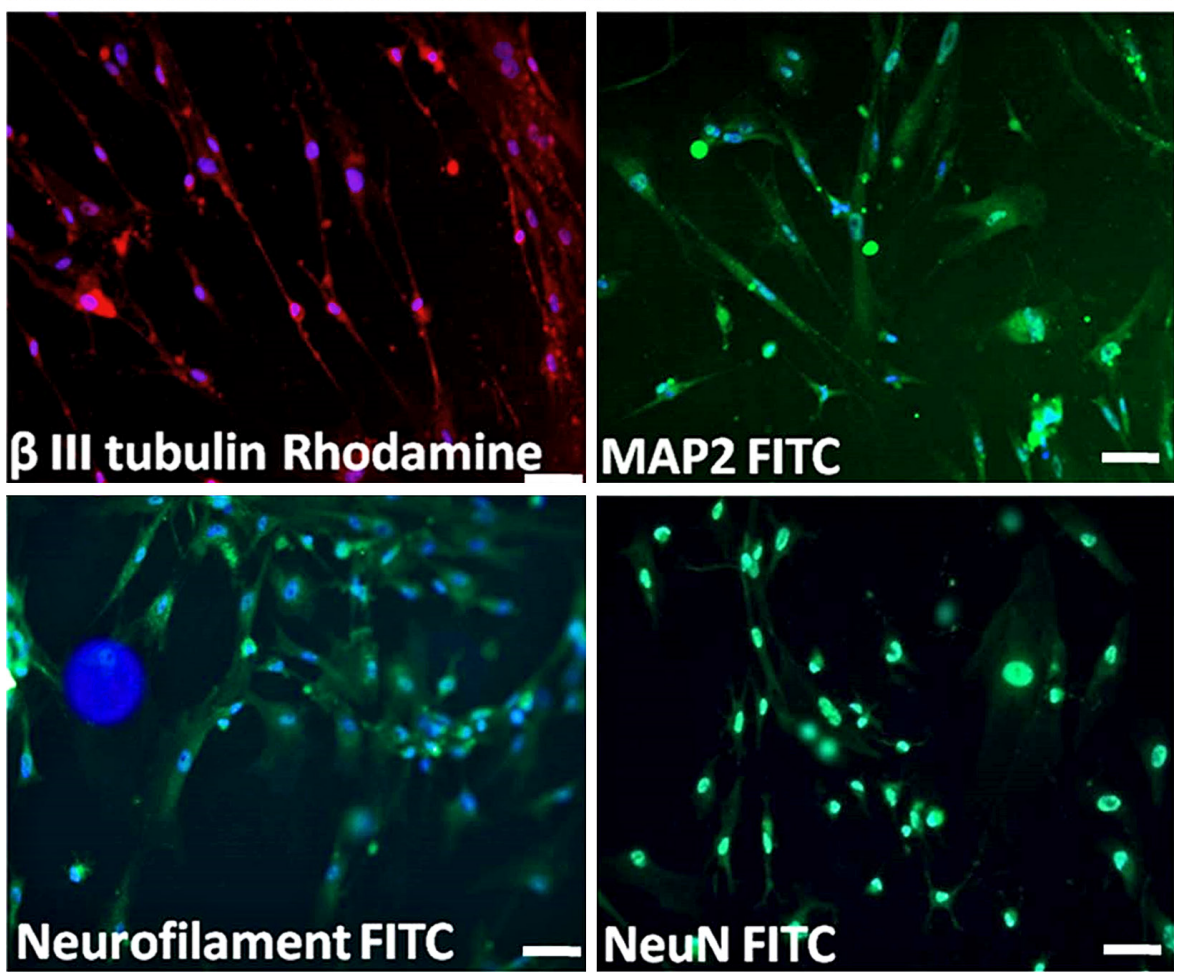

Fig. 4. In vitro differentiation of rat MSCs into neural cells. Phase-contrast image of undifferentiated rat MSCs and differentiated rat MSCs after 12 days in neuronal induction showing neural phenotype. Photomicrographs demonstrate that rat MSCs in neural induction medium differentiate into neural cells expressed neuronal proteins ( $\beta$ III tubulin, microtubule associated protein-2, neurofilament, NeuN), oligodendrocyte $(\mathrm{O} 4)$, and negative for astrocyte (GFAP). Scale bar $=20 \mu \mathrm{m}$.
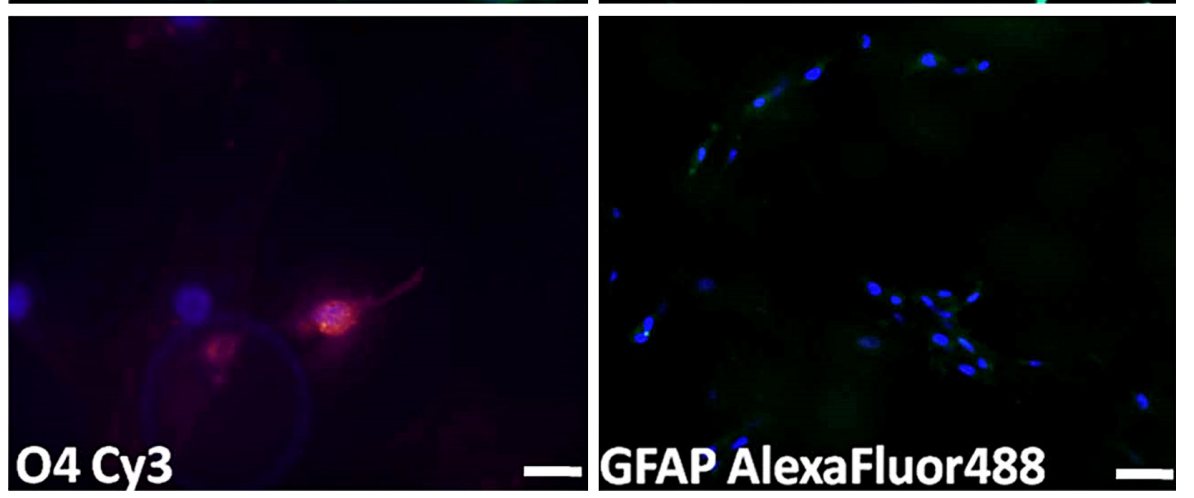

\section{Histology}

GFP-labeled MSCs surviving in the spinal cord around the injury epicenter (Fig. 10c) and those cells differentiated into neurons in vivo express the presence of $\beta$ III tubulin (Fig. 10f). The result shows that the homing of mesodermal origin MSCs converted into an ectodermal neuronal lineage, which is responsible for spinal cord regeneration. 


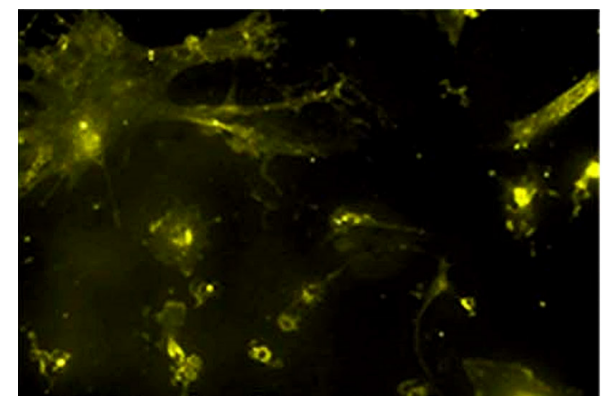

B III tubulin-PerCp \& Nav1.1-PE
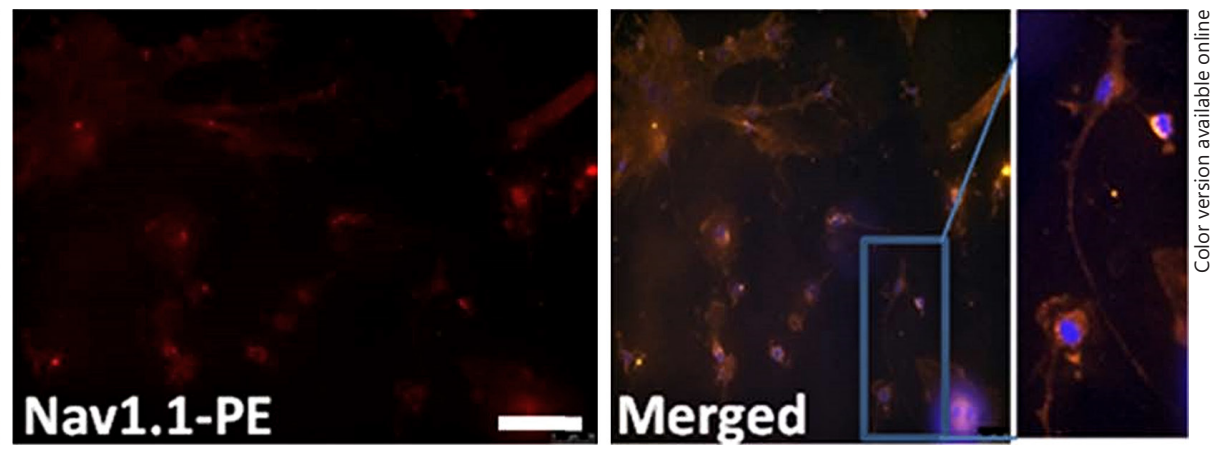

Fig. 5. Characterization of transdifferentiated MSCs. Immunofluorescence analysis of neuronal-induced rat MSCs indicates co-localization of (yellow) $\beta$ III tubulin, a marker for neurons with (red) Nav1.1 (voltage-gated sodium channel). Scale bar $=20 \mu \mathrm{m}$.

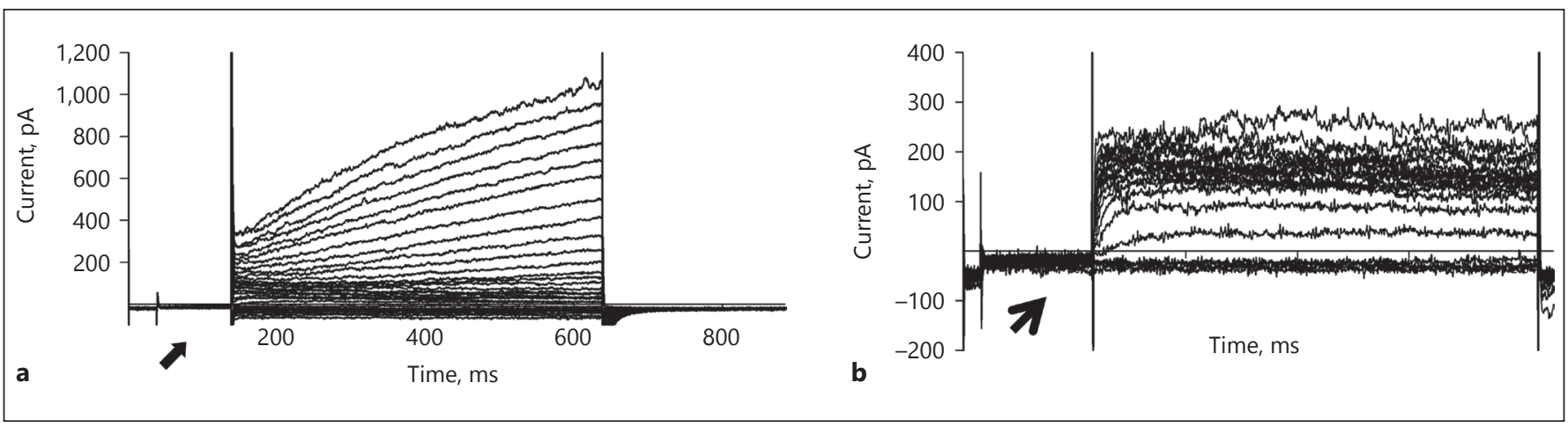

Fig. 6. Patch-clamp studies. a Raw tracing from an MSC showing absence of inward currents at $-40 \mathrm{mV}$ and presence of outward currents at higher depolarizing potentials. The absence of voltagegated sodium currents at the prepulse of $-40 \mathrm{mV}$ (shown by arrow) and the appearance of a family of depolarization-induced outward

\section{Discussion}

The primary mechanical injury to the spinal cord is followed by secondary injury cascades, which contributes to the pathophysiology of SCI. Neurons and O4 are highly vulnerable to insults and $\mathrm{O} 4$ loss ultimately results in demyelination, and severed axons lead to cell death. There is a limited extent of spontaneous replacement of O4 and neurons after SCI in adults $[1,31,32]$. Regeneration of damaged neuronal tissue by stem cell therapy may also replace $\mathrm{O} 4$ for remyelination, neurons at the injured site, secrete factors, and enhance axonal regeneration [33].

In the present study, we showed that rat BM-MSCs express positivity for the panel of markers CD29, CD54, CD73, CD90, and CD105; and negativity for hemato- currents at depolarizing voltages. b Neuronal-induced MSCs show outward rectifying $\mathrm{K}^{+}$current, absence of inward current at -40 $\mathrm{mV}$ (shown by arrow), and further depolarization. There is no voltage-gated sodium current seen. poietic cells by immunostaining as per the classification criteria of MSCs [34]. Marker expression pattern differs, which contribute to the heterogeneous population of rat MSCs. Rat MSCs positively express cell surface antigen CD105 of 13\% and mouse MSC also positively expresses CD105 of $19.1 \%$, and negatively for CD34 and CD45 as reported [35]. The basal expression of the neural markers in rat MSCs was shown negative immunohistochemically. In contrast, undifferentiated human MSCs expressed nestin, enolase 2, and microtubule associated protein 1b (MAP1b) [36]; similarly, mouse MSCs spontaneously express neural markers including $\beta$ III tubulin, NFM, and S100- $\beta$ in a non-induced condition [35].

Previous reports show in vitro neural transdifferentiation of BM-MSC by chemical compounds [37-40],
Muniswami/Kanthakumar/ Kanakasabapathy/Tharion 

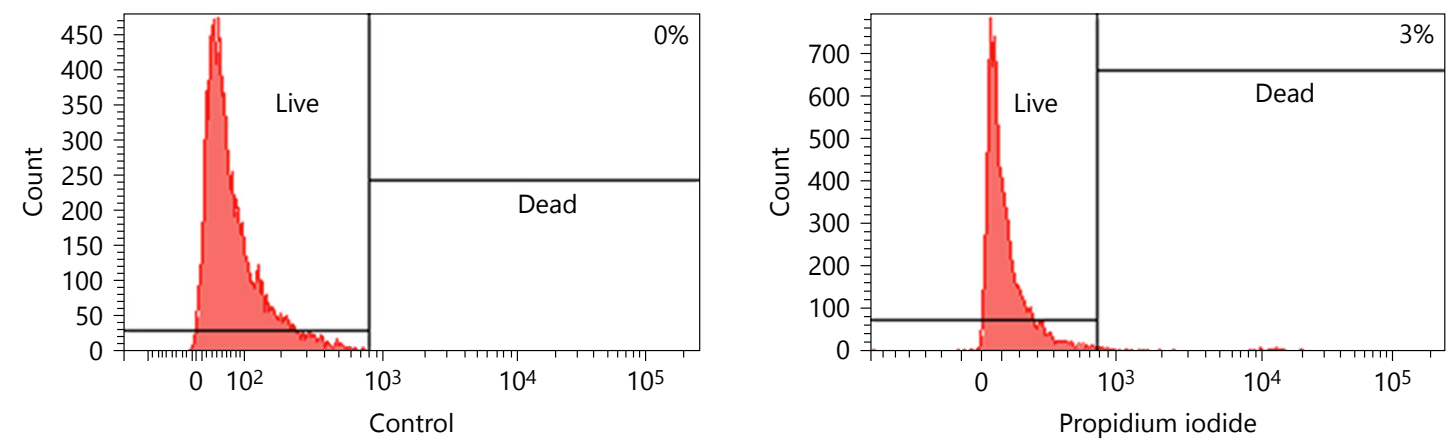

Fig. 7. Viability of MSCs. Propidium iodide-stained cells show 3\%, indicating dead cells, and remaining 97\% of live cells as compared to unstained cells (control).

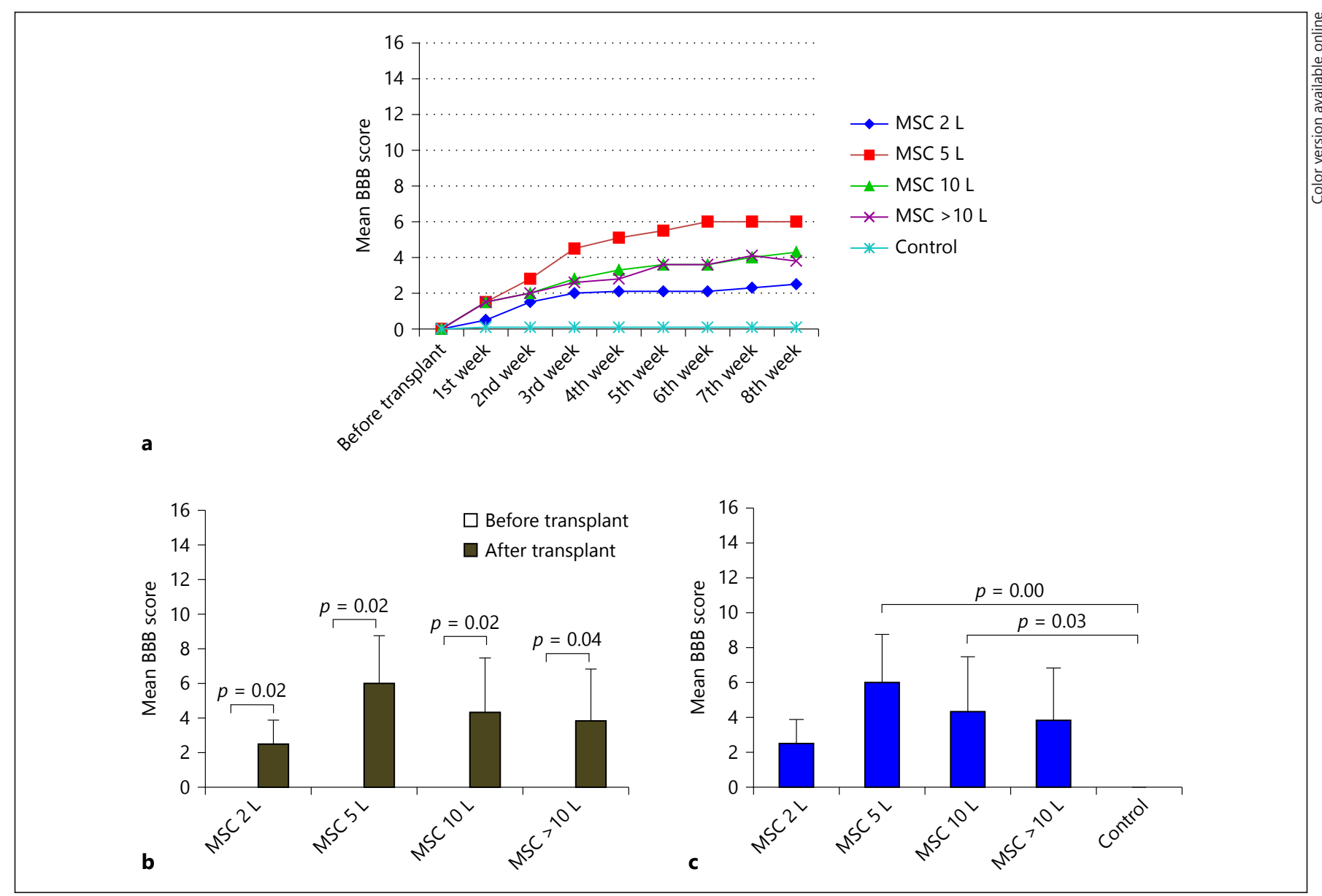

Fig. 8. Hind-limb motor recovery-mean BBB score. All the transplanted groups progressed in BBB score, except control group as shown in (a). In comparison within the groups before and after transplant, significant functional recovery was evident after transplant $(p<0.05 ; \mathbf{b})$. In comparison, between the groups, 5 - and 10 - lakh groups showed significant improvement in motor function $(p<0.05)$, when compared to the control group. But all the other transplanted groups showed functional recovery but statistically did not show significances (c). L, lakhs. 
Fig. 9. Transcranial electrical stimulation and hind-limb motor evoked potential studies. Motor cortex stimulation and their responses were recorded in hind-limb muscle at the end of 8 th week post transplant/SCI. On stimulation, there is no amplitude seen in control (a), but in transplanted rats EMG amplitude is shown with the arrow (b). Amplitude varies based on regeneration in different groups. Statistical analysis showed significant $p<0.05$ in 5-lakh groups compared with control, whereas other groups did not show statistical significances but showed a remarkable increase in mean amplitude (c). L, lakhs.

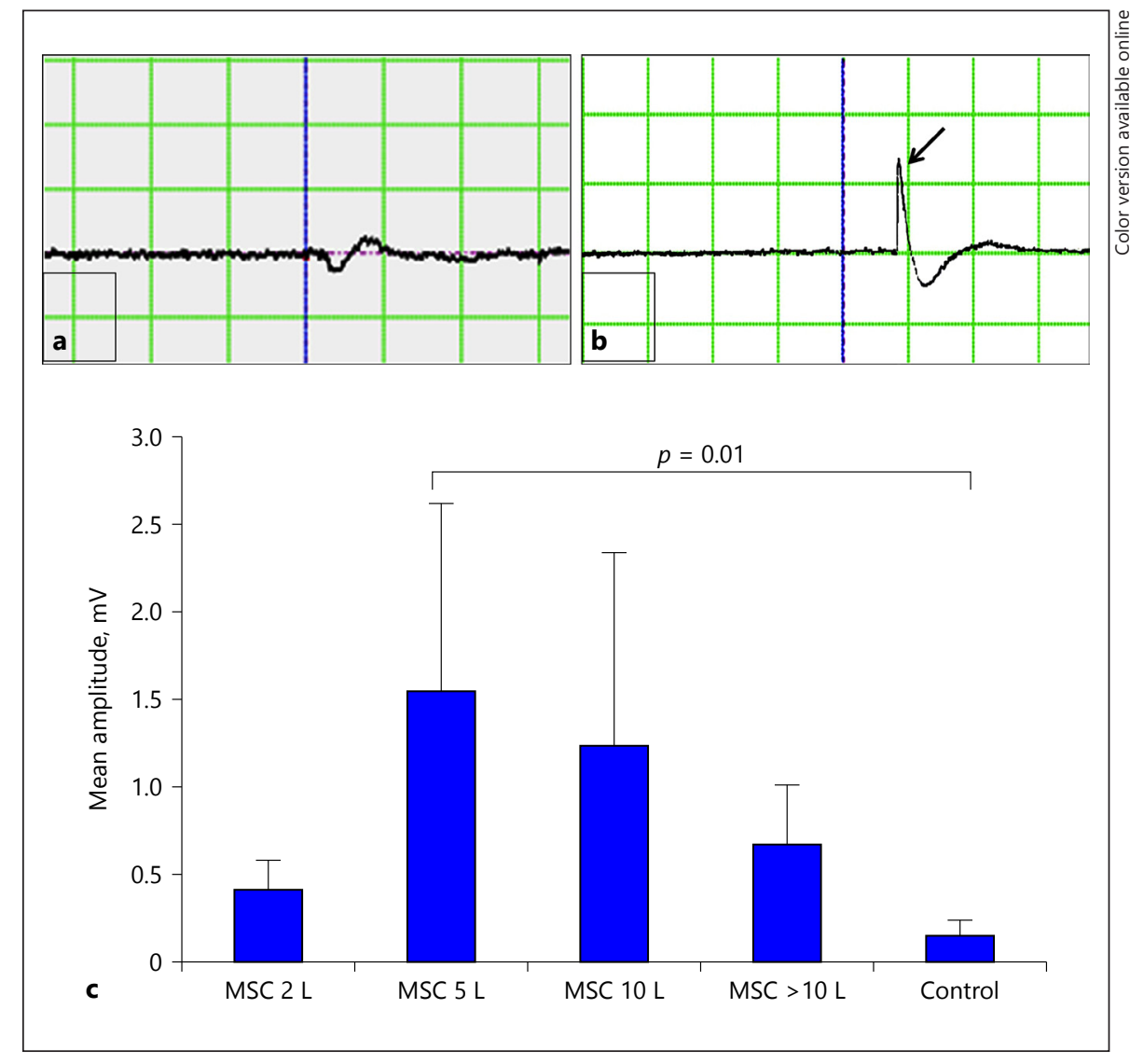

growth factors [12, 41-43], and combination of chemicals with growth factors [44, 45]. RA mediated neurite outgrowth in cultured embryonic dorsal root ganglia, spinal cord, and adult dorsal root ganglia [46-49]. We used RA, B27, and bFGF for neuronal induction, and this method of induction was followed from the published literature [11]. Similarly, the other researchers used FGF and RA with/without nerve growth factor on fibronectin as a feeder layer for in vitro neuronal differentiation of human BM-MSCs [12, 50-52]. On exposure to neurogenic medium, rat MSCs exhibit neural phenotype and expressed neuron markers $\beta$ III tubulin, MAP2, NeuN, $\mathrm{NF}$, and O4, but does not show positive for GFAP astroglial cells. The acquisition of $\beta$ III tubulin and voltagegated sodium channel of induced MSC has been suggested to result in neural differentiation and has been subsequently checked for excitable functional properties by patch-clamp study, but found to have an inability to fire inward voltage-gated sodium current. It has been reported that $19 \%$ of rat MSCs had voltage-gated sodium current and $8 \%$ had voltage-gated calcium currents. The profile of outward currents seen in our experiments is different from that which is reported and seems to be fast-activating delayed rectifier potassium channels [53]. When MSCs were co-cultured with cerebellar granule neurons, they demonstrated the presence of neuron-like phenotype cells, which were able to fire single-action potentials and respond to neurotransmitters like GABA, glutamate, and glycine [54]. In another experiment on human MSC exposed to induction cocktail, these induced neurons express neurotransmitters and are electrophysiologically responsive to exogenous neurotransmitters [11]. In vitro transdifferentiation of mesodermal origin BM-MSCs to ectodermal neuronal lineages has been explored in the current study. However, skepticism has been aroused in in vitro transdifferentiation. Further alternative methods of neuronal induction will be carried out in future studies.

MSCs transplanted 1 week after impact SCI at the T8 level in female Sprague-Dawley rats showed cell survival and differentiation and remarkable improvement in locomotor recovery of SCI rats. The effect of transplanted MSCs in injured cord showed reduced lesion cavitation and white matter loss [55]. The therapeutic window pe-
Muniswami/Kanthakumar/ Kanakasabapathy/Tharion 


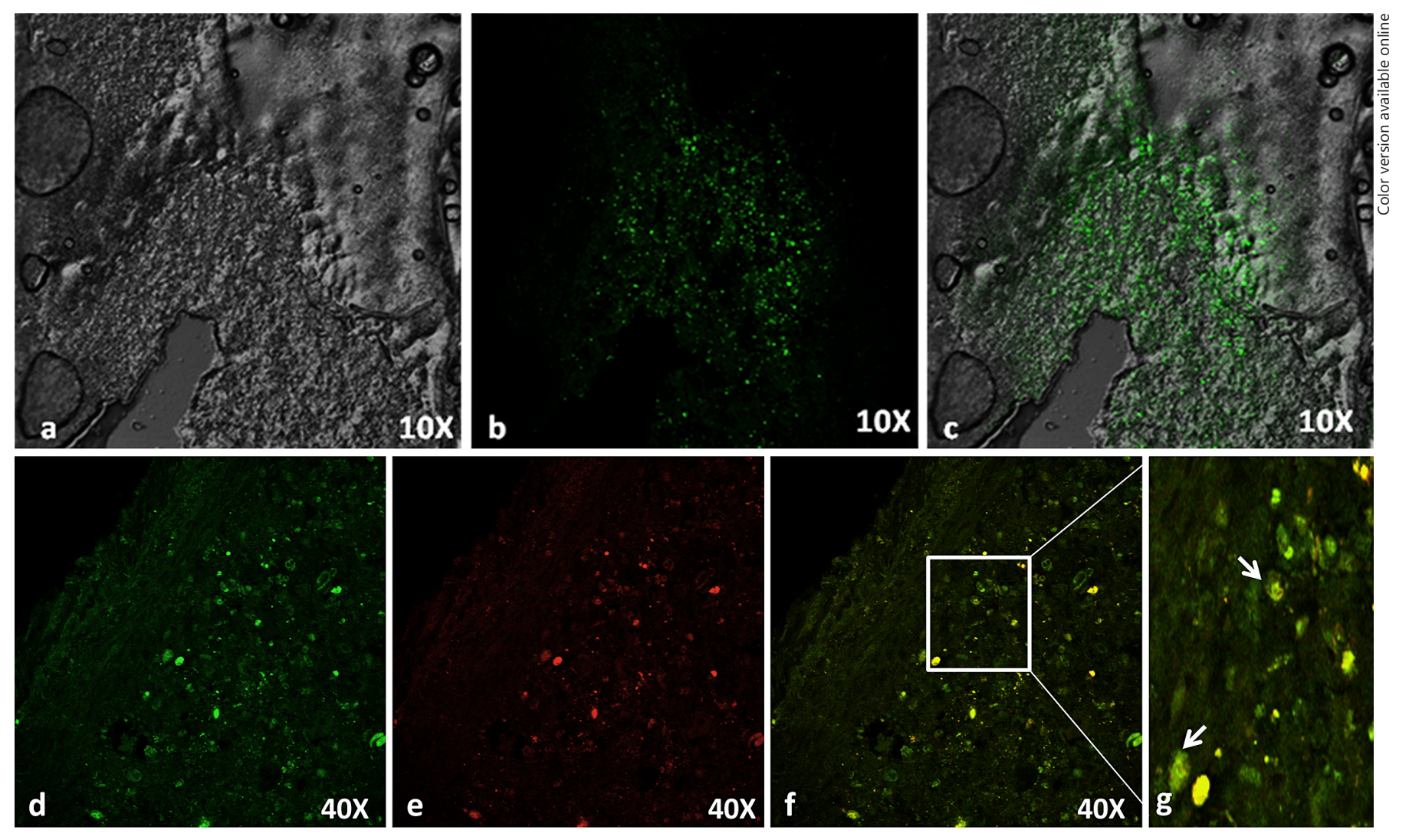

Fig. 10. Histology of MSC-transplanted rat spinal cord. Green fluorescent protein (GFP)-labeled rat MSC in injured rat spinal cord. a Phase contrast. b GFP cells around the injury epicenter. c Merged image of (a) and (b). Immunohistochemistry on longitudinal sections of the injured spinal cord of rats 2 weeks after transplanta-

riod for transplantation is also a key issue, as evidence suggests that cell engraftment and improved functional outcome if transplanted in 1 week, but $<14$ days after injury [56-58]. Data suggest that the dose of 3 lakhs [56, 59, 60] and 4.5 lakhs [58] of MSCs showed better functional outcomes in SCI rat models.

The underlying molecular mechanism of SCI and the use of MSCs in SCI activated caspase-3, which in turn contributed to apoptosis via poly(ADP-ribose) polymerase (PARP). The upregulation of PARP after SCI plays a major role in the execution of apoptosis in the injured spinal cord. This therapeutic intervention site exploited with the use of PARP inhibitors to reduce the inflammation and cell death after spinal cord trauma [61-63]. Similarly, rat MSC reduces activated caspase-3, thereby limiting secondary damage after SCI. This anticaspase- 3 activity of rat MSCs leads to the downregulation of apoptotic proteins and preservation of neurons and $\mathrm{O} 4$ in rat-MSC-treated rats [64-66].

Motor Recoveryafter Transplantation of BM-MSCs Rat Models of Spinal Cord Injury tion. Confocal immunofluorescence analysis of cryo sections indicates co-localization (green) GFP-labeled cells (d) with (red) $\beta I I I$ tubulin (e). Merged image (yellow) indicates differentiated neurons $(\mathbf{f}, \mathbf{g})$. Transplanted-rat MSC differentiates into neurons in vivo after SCI.

MSC has various effects like inflammatory modulation $[67,68]$, secrete and/or induce the protective molecules such as brain-derived neurotrophic factor and glial cell line-derived neurotrophic factor [69-71], and create a more permissive environment for axonal regeneration $[56,69,72,73]$, nerve growth factor, vascular endothelial growth factor [74], hepatocyte growth factor [75], ciliary neurotrophic factor, and bFGF [76-78]. These factors play a role in several processes, including neuroprotection, neurogenesis, vascularization, and scar inhibition.

Recovery of hind-limb motor function improved slowly but steadily over the course of the 8-week observation period in the rat-MSC-treated groups. As per dose-response relationship, the 2-lakh cell group retained the lowest hind-limb motor recovery of $2.5 \pm 1.37$ among all the treated groups. The 5-lakh cell group achieved the maximum mean BBB score of $6 \pm 2.7$ as compared to a higher dose of 10 lakh $(4.3 \pm 3.1)$ and more than 10 lakh groups $(3.8 \pm 2.9)$. The 10 lakh and 
more than 10 lakh groups decline in beneficial effect may be due to saturation or difficulty to accommodate higher numbers of transplanted cells into the injured spinal cord. Rats in the transplanted groups showed improvement on the $\mathrm{BBB}$ scale relative to the injured control group. A similar study including rat-MSC-treated animals compared to the injured rats found significant functional recovery after 2 weeks of rat MSC transplantation and the number of intact axons across the injury site were increased [66]. Animals with SCI reported longer MEP latency with reduced amplitude as compared to human-MSC-treated rats [79]. In our study, similar MEP waves were observed. An EMG amplitude of 5 lakhs of cell transplanted group showed a maximum of $1.5 \pm 1.0 \mathrm{mV}$ as compared to 10 lakh $(1.2 \pm 1.1 \mathrm{mV})$ and more than 10 lakh groups $(0.6 \pm 0.3 \mathrm{mV})$. The amplitude of motor-evoked potential depends on the continuation of neuronal connection and amount of fibers regenerated, which plays a role in conduction. Like the BBB, the amplitude of 2 lakhs of the cell-transplanted group has mild recovery waves of $0.4 \pm 0.1 \mathrm{mV}$ with that of other dosages. In control rats, even with the stimulation of motor cortex, there was neither any amplitude nor lesser amplitude waves recorded. This shows that there is no spontaneous recovery after SCI. However, all the treated groups elicit hind-limb motor functional recovery after SCI is evaluated by BBB and EMG as compared to control. Thus, MSC plays a role in transplant-mediated repair in SCI. In the dose-response relationship study, the 5-lakh group showed promising outcomes in BBB score, as well as motor-evoked potential study among the treated groups. Therefore, 5 lakh cells could be the optimum therapeutic dose in SCI of rat models.
Rat MCSs increase the number of surviving neurons and $\mathrm{O} 4$ after 14 days of transplantation [66]. In our study, 2 weeks after transplantation, we found rat MSC survived and distributed around the cavities of the injured spinal cord. The transplanted rat MSC differentiated into neurons in the injured spinal cord.

In conclusion, the transplanted rat MSCs that survived the injury transdifferentiated and showed significant improvement in the functional recovery of spinal cord injured rats. This functional recovery may be due to neuroprotection, remyelination of demyelinated axons, and enhances regeneration of an injured cord by BM-MSCs.

\section{Acknowledgments}

This study was financially supported by Department of Biotechnology, Ministry of Science and Technology, Government of India.

\section{Disclosure Statement}

All contributing authors have no conflicts of interest for this study. The manuscript complies with the standards of ICMJE.

\section{Author Contribution}

D.M.M. was involved in design, experimental studies, data acquisition, data analysis, manuscript preparation, and literature search. P.K. contributed to electrophysiology (patch-clamp studies). I.K. was involved in design, manuscript editing, and manuscript review. G.T. contributed toward getting fund, designing, conducting experimental studies, manuscript editing, and manuscript reviewing.

\section{References}

$\checkmark 1$ Crowe MJ, Bresnahan JC, Shuman SL, Masters JN, Beattie MS: Apoptosis and delayed degeneration after spinal cord injury in rats and monkeys. Nat Med 1997;3:7376.

-2 Dumont RJ, Okonkwo DO, Verma S, Hurlbert RJ, Boulos PT, Ellegala DB, et al: Acute spinal cord injury, part I: pathophysiologic mechanisms. Clin Neuropharmacol 2001;24: 254-264.

-3 Kwon BK, Borisoff JF, Tetzlaff W: Molecular targets for therapeutic intervention after spinal cord injury. Mol Interv 2002;2:244258.

4 Furuya T, Hashimoto M, Koda M, Okawa A, Murata A, Takahashi K, et al: Treatment of rat spinal cord injury with a Rho-kinase inhibitor and bone marrow stromal cell transplantation. Brain Res 2009; 1295:192-202.

5 Parr AM, Kulbatski I, Wang XH, Keating A, Tator CH: Fate of transplanted adult neural stem/progenitor cells and bone marrow-derived mesenchymal stromal cells in the injured adult rat spinal cord and impact on functional recovery. Surg Neurol 2008;70: 600-607; discussion 607.

6 Horwitz EM, Le Blanc K, Dominici M, Mueller I, Slaper-Cortenbach I, Marini FC, et al: Clarification of the nomenclature for MSC: the International Society for Cellular Therapy position statement. Cytotherapy 2005;7:393-395.

$>7$ Rickard DJ, Sullivan TA, Shenker BJ, Leboy PS, Kazhdan I: Induction of rapid osteoblast differentiation in rat bone marrow stromal cell cultures by dexamethasone and BMP-2. Dev Biol 1994;161:218-228.

$>8$ Pereira RF, Halford KW, O'Hara MD, Leeper DB, Sokolov BP, Pollard MD, et al: Cultured adherent cells from marrow can serve as longlasting precursor cells for bone, cartilage, and lung in irradiated mice. Proc Natl Acad Sci U S A 1995;92:4857-4861.

$\checkmark 9$ Bornes TD, Adesida AB, Jomha NM: Mesenchymal stem cells in the treatment of traumatic articular cartilage defects: a comprehensive review. Arthritis Res Ther 2014;16:432.

$>10$ Ferrari G, Cusella-De Angelis G, Coletta M, Paolucci E, Stornaiuolo A, Cossu G, et al: Muscle regeneration by bone marrow-derived myogenic progenitors. Science 1998; 279:1528-1530. 
11 Greco SJ, Zhou C, Ye JH, Rameshwar P: A method to generate human mesenchymal stem cell-derived neurons which express and are excited by multiple neurotransmitters. Biol Proced Online 2008;10:90-101.

-12 Sanchez-Ramos J, Song S, Cardozo-Pelaez F, Hazzi C, Stedeford T, Willing A, et al: Adult bone marrow stromal cells differentiate into neural cells in vitro. Exp Neurol 2000;164: 247-256.

13 Suzuki H, Taguchi T, Tanaka H, Kataoka H, Li Z, Muramatsu K, et al: Neurospheres induced from bone marrow stromal cells are multipotent for differentiation into neuron, astrocyte, and oligodendrocyte phenotypes. Biochem Biophys Res Commun 2004;322: 918-922.

14 Lei Z, Yongda L, Jun M, Yingyu S, Shaoju Z, Xinwen Z, et al: Culture and neural differentiation of rat bone marrow mesenchymal stem cells in vitro. Cell Biol Int 2007;31:916923.

-15 Alexanian AR, Maiman DJ, Kurpad SN, Gennarelli TA: In vitro and in vivo characterization of neurally modified mesenchymal stem cells induced by epigenetic modifiers and neural stem cell environment. Stem Cells Dev 2008;17:1123-1130.

- 16 Tondreau T, Dejeneffe M, Meuleman N, Stamatopoulos B, Delforge A, Martiat P, et al: Gene expression pattern of functional neuronal cells derived from human bone marrow mesenchymal stromal cells. BMC Genomics 2008;9:166.

\17 Muñoz-Elias G, Marcus AJ, Coyne TM, Woodbury D, Black IB: Adult bone marrow stromal cells in the embryonic brain: engraftment, migration, differentiation, and longterm survival. J Neurosci Off J Soc Neurosci 2004;24:4585-4595.

-18 Brazelton TR, Rossi FM, Keshet GI, Blau HM: From marrow to brain: expression of neuronal phenotypes in adult mice. Science 2000; 290:1775-1779.

19 Mezey E, Key S, Vogelsang G, Szalayova I, Lange GD, Crain B: Transplanted bone marrow generates new neurons in human brains. Proc Natl Acad Sci U S A 2003;100:13641369.

20 Deng YB, Yuan QT, Liu XG, Liu XL, Liu Y, Liu ZG, et al: Functional recovery after rhesus monkey spinal cord injury by transplantation of bone marrow mesenchymal-stem cell-derived neurons. Chin Med J 2005;118:15331541.

-21 Deng YB, Liu XG, Liu ZG, Liu XL, Liu Y, Zhou GQ: Implantation of BM mesenchymal stem cells into injured spinal cord elicits de novo neurogenesis and functional recovery: evidence from a study in rhesus monkeys. Cytotherapy 2006;8:210-214.

22 Urdzíková L, Jendelová P, Glogarová K, Burian $\mathrm{M}$, Hájek M, Syková E: Transplantation of bone marrow stem cells as well as mobilization by granulocyte-colony stimulating factor promotes recovery after spinal cord injury in rats. J Neurotrauma 2006;23:1379-1391.
Chopp M, Zhang XH, Li Y, Wang L, et al: Spinal cord injury in rat: treatment with bone marrow stromal cell transplantation. Neuroreport 2000;11:3001-3005.

-24 Lee J, Kuroda S, Shichinohe H, Ikeda J, Seki T, Hida K, et al: Migration and differentiation of nuclear fluorescence-labeled bone marrow stromal cells after transplantation into cerebral infarct and spinal cord injury in mice. Neuropathology 2003;23:169-180.

25 Syková E, Jendelová P: Magnetic resonance tracking of implanted adult and embryonic stem cells in injured brain and spinal cord. Ann N Y Acad Sci 2005;1049:146-160.

26 Wu S, Suzuki Y, Ejiri Y, Noda T, Bai H, Kitada $\mathrm{M}$, et al: Bone marrow stromal cells enhance differentiation of cocultured neurosphere cells and promote regeneration of injured spinal cord. J Neurosci Res 2003;72: 343-351.

27 Le Blanc K: Immunomodulatory effects of fetal and adult mesenchymal stem cells. Cytotherapy 2003;5:485-489.

28 Ohtaki H, Ylostalo JH, Foraker JE, Robinson AP, Reger RL, Shioda S, et al: Stem/progenitor cells from bone marrow decrease neuronal death in global ischemia by modulation of inflammatory/immune responses. Proc Natl Acad Sci 2008; 105:14638-14643.

29 Kassis I, Grigoriadis N, Gowda-Kurkalli B, et al: Neuroprotection and immunomodulation with mesenchymal stem cells in chronic experimental autoimmune encephalomyelitis. Arch Neurol 2008;65:753-761.

30 Basso DM, Beattie MS, Bresnahan JC: A sensitive and reliable locomotor rating scale for open field testing in rats. J Neurotrauma 1995; 12:1-21.

31 Ohori Y, Yamamoto S, Nagao M, Sugimori M, Yamamoto N, Nakamura K, et al: Growth factor treatment and genetic manipulation stimulate neurogenesis and oligodendrogenesis by endogenous neural progenitors in the injured adult spinal cord. J Neurosci Off J Soc Neurosci 2006;26:11948-11960.

32 Casha S, Yu WR, Fehlings MG: Oligodendroglial apoptosis occurs along degenerating axons and is associated with FAS and p75 expression following spinal cord injury in the rat. Neuroscience 2001;103:203-218.

33 Klein S, Svendsen CN: Stem cells in the injured spinal cord: reducing the pain and increasing the gain. Nat Neurosci 2005;8:259260.

34 Dominici M, Le Blanc K, Mueller I, SlaperCortenbach I, Marini F, Krause D, et al: Minimal criteria for defining multipotent mesenchymal stromal cells. The International Society for Cellular Therapy position statement. Cytotherapy 2006;8:315-317.

- 35 Deng J, Petersen BE, Steindler DA, Jorgensen ML, Laywell ED: Mesenchymal stem cells spontaneously express neural proteins in culture and are neurogenic after transplantation. Stem Cells 2006;24:1054-1064.

- 36 Montzka K, Lassonczyk N, Tschöke B, Neuss $S$, Führmann T, Franzen R, et al: Neural dif- ferentiation potential of human bone marrow-derived mesenchymal stromal cells: misleading marker gene expression. BMC Neurosci 2009; 10:16.

37 Woodbury D, Schwarz EJ, Prockop DJ, Black IB: Adult rat and human bone marrow stromal cells differentiate into neurons. J Neurosci Res 2000;61:364-370.

38 Deng W, Obrocka M, Fischer I, Prockop DJ: In vitro differentiation of human marrow stromal cells into early progenitors of neural cells by conditions that increase intracellular cyclic AMP. Biochem Biophys Res Commun 2001;282:148-152.

-39 Muñoz-Elías G, Woodbury D, Black IB: Marrow stromal cells, mitosis, and neuronal differentiation: stem cell and precursor functions. Stem Cells 2003;21:437-448.

40 Jori FP, Napolitano MA, Melone MA, Cipollaro M, Cascino A, Altucci L, et al: Molecular pathways involved in neural in vitro differentiation of marrow stromal stem cells. J Cell Biochem 2005;94:645-655.

41 Tao H, Rao R, Ma DD: Cytokine-induced stable neuronal differentiation of human bone marrow mesenchymal stem cells in a serum/ feeder cell-free condition. Dev Growth Differ 2005; 47:423-433.

42 Jin K, Mao XO, Batteur S, Sun Y, Greenberg DA: Induction of neuronal markers in bone marrow cells: differential effects of growth factors and patterns of intracellular expression. Exp Neurol 2003;184:78-89.

-43 Jiang Y, Henderson D, Blackstad M, Chen A, Miller RF, Verfaillie CM: Neuroectodermal differentiation from mouse multipotent adult progenitor cells. Proc Natl Acad Sci U S A 2003;100(suppl 1):11854-11860.

44 Scintu F, Reali C, Pillai R, Badiali M, Sanna MA, Argiolu F, et al: Differentiation of human bone marrow stem cells into cells with a neural phenotype: diverse effects of two specific treatments. BMC Neurosci 2006;7:14.

45 Hermann A, Liebau S, Gastl R, Fickert S, Habisch HJ, Fiedler J, et al: Comparative analysis of neuroectodermal differentiation capacity of human bone marrow stromal cells using various conversion protocols. J Neurosci Res 2006;83:1502-1514.

46 Corcoran J, Maden M: Nerve growth factor acts via retinoic acid synthesis to stimulate neurite outgrowth. Nat Neurosci 1999;2:307-308.

47 Corcoran J, Shroot B, Pizzey J, Maden M: The role of retinoic acid receptors in neurite outgrowth from different populations of embryonic mouse dorsal root ganglia. J Cell Sci 2000;113(Pt 14):2567-2574.

48 Corcoran J, So PL, Barber RD, Vincent KJ, Mazarakis ND, Mitrophanous KA, et al: Retinoic acid receptor beta2 and neurite outgrowth in the adult mouse spinal cord in vitro. J Cell Sci 2002;115(Pt 19):3779-3786.

49 So PL, Yip PK, Bunting S, Wong LF, Mazarakis ND, Hall S, et al: Interactions between retinoic acid, nerve growth factor and sonic hedgehog signalling pathways in neurite outgrowth. Dev Biol 2006;298:167-175. 
-50 Vogel W, Grünebach F, Messam CA, Kanz L, Brugger W, Bühring $\mathrm{HJ}$ : Heterogeneity among human bone marrow-derived mesenchymal stem cells and neural progenitor cells. Haematologica 2003;88:126-133.

51 Kim BJ, Seo JH, Bubien JK, Oh YS: Differentiation of adult bone marrow stem cells into neuroprogenitor cells in vitro. Neuroreport 2002;13:1185-1188.

52 Reyes M, Verfaillie CM: Characterization of multipotent adult progenitor cells, a subpopulation of mesenchymal stem cells. Ann N Y Acad Sci 2001;938:231-233; discussion 233235.

53 Li GR, Deng XL, Sun H, Chung SS, Tse HF, Lau CP: Ion channels in mesenchymal stem cells from rat bone marrow. Stem Cells 2006; 24:1519-1528.

-54 Wislet-Gendebien S, Hans G, Leprince P, Rigo JM, Moonen G, Rogister B: Plasticity of cultured mesenchymal stem cells: switch from nestin-positive to excitable neuron-like phenotype. Stem Cells 2005;23:392-402.

-55 Alexanian AR, Fehlings MG, Zhang Z, Maiman DJ: Transplanted neurally modified bone marrow-derived mesenchymal stem cells promote tissue protection and locomotor recovery in spinal cord injured rats. Neurorehabil Neural Repair 2011;25:873-880.

- 56 Hofstetter CP, Schwarz EJ, Hess D, Widenfalk J, El Manira A, Prockop DJ, et al: Marrow stromal cells form guiding strands in the injured spinal cord and promote recovery. Proc Natl Acad Sci 2002;99:2199-2204.

57 Okano H: Stem cell biology of the central nervous system. J Neurosci Res 2002;69:698-707.

-58 Torres-Espín A, Hernández J, Navarro X: Gene expression changes in the injured spinal cord following transplantation of mesenchymal stem cells or olfactory ensheathing cells. PLoS One 2013;8:e76141.

59 Chen D, Zeng W, Fu Y, Gao M, Lv G: Bone marrow mesenchymal stem cells combined with minocycline improve spinal cord injury in a rat model. Int J Clin Exp Pathol 2015;8: 11957-11969.

60 Li F, Fei D, Sun L, Zhang S, Yuan Y, Zhang L, et al: Neuroprotective effect of bone marrow stromal cell combination with atorvastatin in rat model of spinal cord injury. Int J Clin Exp Med 2014;7:4967-4974.
61 Genovese T, Mazzon E, Di Paola R, Muià C, Threadgill MD, Caputi AP, et al: Inhibitors of poly(ADP-ribose) polymerase modulate signal transduction pathways and the development of bleomycin-induced lung injury. J Pharmacol Exp Ther 2005;313:529-538.

62 Keane RW, Kraydieh S, Lotocki G, Bethea JR, Krajewski S, Reed JC, et al: Apoptotic and anti-apoptotic mechanisms following spinal cord injury. J Neuropathol Exp Neurol 2001; 60422-429.

63 Scott GS, Szabó C, Hooper DC: Poly(ADPribose) polymerase activity contributes to peroxynitrite-induced spinal cord neuronal cell death in vitro. J Neurotrauma 2004;21: 1255-1263.

64 Movsesyan VA, Yakovlev AG, Fan L, Faden AI: Effect of serine protease inhibitors on posttraumatic brain injury and neuronal apoptosis. Exp Neurol 2001;167:366-375.

65 Ozawa H, Keane RW, Marcillo AE, Diaz PH, Dietrich WD: Therapeutic strategies targeting caspase inhibition following spinal cord injury in rats. Exp Neurol 2002;177:306-313.

66 Dasari VR, Spomar DG, Cady C, Gujrati M, Rao JS, Dinh DH: Mesenchymal stem cells from rat bone marrow downregulate caspase-3-mediated apoptotic pathway after spinal cord injury in rats. Neurochem Res 2007;32:2080-2093.

67 Abrams MB, Dominguez C, Pernold K, Reger R, Wiesenfeld-Hallin Z, Olson L, et al: Multipotent mesenchymal stromal cells attenuate chronic inflammation and injury-induced sensitivity to mechanical stimuli in experimental spinal cord injury. Restor Neurol Neurosci 2009;27:307-321.

68 Nakajima H, Uchida K, Guerrero AR, Watanabe S, Sugita D, Takeura N, et al: Transplantation of mesenchymal stem cells promotes an alternative pathway of macrophage activation and functional recovery after spinal cord injury. J Neurotrauma 2012;29:1614-1625.

69 Himes BT, Neuhuber B, Coleman C, Kushner R, Swanger SA, Kopen GC, et al: Recovery of function following grafting of human bone marrow-derived stromal cells into the injured spinal cord. Neurorehabil Neural Repair 2006;20:278-296.

70 Quertainmont R, Cantinieaux D, Botman O, Sid S, Schoenen J, Franzen R: Mesenchymal stem cell graft improves recovery after spinal cord injury in adult rats through neurotrophic and pro-angiogenic actions. PLoS One 2012; 7:e39500.

71 Lu P, Jones LL, Tuszynski MH: BDNF-expressing marrow stromal cells support extensive axonal growth at sites of spinal cord injury. Exp Neurol 2005;191:344-360.

72 Ankeny DP, McTigue DM, Jakeman LB: Bone marrow transplants provide tissue protection and directional guidance for axons after contusive spinal cord injury in rats. Exp Neurol 2004;190:17-31.

73 Koda M, Kamada T, Hashimoto M, Murakami M, Shirasawa H, Sakao S, et al: Adenovirus vector-mediated ex vivo gene transfer of brain-derived neurotrophic factor to bone marrow stromal cells promotes axonal regeneration after transplantation in completely transected adult rat spinal cord. Eur Spine J 2007; 16:2206-2214.

74 Sun Y, Jin K, Xie L, Childs J, Mao XO, Logvinova $A$, et al: VEGF-induced neuroprotection, neurogenesis, and angiogenesis after focal cerebral ischemia. J Clin Invest 2003;111: 1843-1851.

75 Neuss S, Becher E, Wöltje M, Tietze L, Jahnen-Dechent W: Functional expression of HGF and HGF receptor/c-met in adult human mesenchymal stem cells suggests a role in cell mobilization, tissue repair, and wound healing. Stem Cells 2004;22:405-414.

76 Neuhuber B, Timothy Himes B, Shumsky JS, Gallo G, Fischer I: Axon growth and recovery of function supported by human bone marrow stromal cells in the injured spinal cord exhibit donor variations. Brain Res 2005; 1035:73-85.

77 Chen Q, Long Y, Yuan X, Zou L, Sun J, Chen $S$, et al: Protective effects of bone marrow stromal cell transplantation in injured rodent brain: synthesis of neurotrophic factors. J Neurosci Res 2005;80:611-619.

78 Chen CJ, Ou YC, Liao SL, Chen WY, Chen SY, $\mathrm{Wu} \mathrm{CW}$, et al: Transplantation of bone marrow stromal cells for peripheral nerve repair. Exp Neurol 2007;204:443-453.

-79 Lee KH, Suh-Kim H, Choi JS, Jeun SS, Kim EJ, Kim SS, et al: Human mesenchymal stem cell transplantation promotes functional recovery following acute spinal cord injury in rats. Acta Neurobiol Exp (Warsz) 2007;67:13-22. 